\title{
Morphology and Dissection Technique of the Kidney of the Grey Snapper Lutjanus griseus (Teleostei: Lutjanidae)
}

\author{
Morfología y Técnica de Disección del Riñón del Pargo Gris Lutjanus griseus (Teleostei: Lutjanidae)
}

\author{
Abraham Kobelkowsky
}

KOBELKOWSKY, A. Morphology and dissection technique of the kidney of the grey snapper Lutjanus griseus (Teleostei: Lutjanidae). Int. J. Morphol., 31(2):553-561, 2013.

SUMMARY: In order to describe the morphology of the kidney and implement its dissection technique, specimens of the grey snapper Lutjanus griseus were analyzed. The morphology of the kidney fits with the structural pattern of the higher teleosts, consisting of a large fusion of the right kidney with the left, with the exception of the anterior renal lobes. Both anterior renal lobes are separated by the retractores dorsales muscles and by the anchorage of the gas bladder to the vertebrae. Some cranial and spinal nerves, as well as ribs, blood vessels, the Baudelot's ligament, the sinus venosus of the heart, the precaudal vertebrae, and the gas bladder mark the surface of the kidney. The archinephric ducts are connected with the urinary bladder, from which the common urinary and urogenital leaves.

KEY WORDS: Mesonephros; Fishes; Anatomy; Renal morphology; Dissection technique.

\section{INTRODUCTION}

Perciformes is the most diverse order of fishes; it includes 160 families, 1,539 genera, and about 10,033 species (Nelson, 2006). Within this order there is the family Lutjanidae, widely distributed in tropical and subtropical seas of the Atlantic, Pacific, and Indian oceans; it is composed of 17 genera, which includes Lutjanus with about 64 species.

The grey snapper, Lutjanus griseus (L.1758) ranges from Massachusetts, United States to Rio de Janeiro, Brazil, and the Gulf of Mexico (Castro-Aguirre, 1978). This species is found between five and $18 \mathrm{~m}$ deep, and constitutes important regional fisheries.

In fishes there are two basic anatomical types of kidneys, pronephric and mesonephric (Lagler et al., 1977). In most fishes the pronephros is transitional as its functions in early life are later taken over by the mesonephros. The teleosts have a mesonephric kidney, which consists of excretory, endocrine and hemopoietic tissues (Hickman \& Trump, 1969). According to Reimschussel (2001) the cranial or "head kidney" contains hematopoietic, lymphoid, and endocrine tissue, and the "caudal kidney" is composed of nephrons surrounded by hematopoietic and lymphoid tissue dispersed throughout the organ. According to Grassi Milano et al. (1997) steroidogenic and catecholaminergic chromaffin cells are found in the head kidney, which is pronephric in origin and subsequently transformed into a hematopoietic organ. The excretory function is performed by the nephrons, the endocrine function is performed by the adrenocortical homolog or interrenal tissue and by the corpuscle of Stannius (Youson et al., 1989). The hematopoietic tissue is distributed around all structures of the kidney, especially around the renal corpuscles (Sakai, 1985).

The gross anatomy of the teleost kidney in general has been scarcely described (Gérard, 1954; Ogawa, 1961; Mok, 1981; Kobelkowsky, 2000). Only a few authors have focused macroscopic studies on specific teleosts, such as Lagler et al., on Salmo gairdneri, Chiasson (1980) on Perca flavecens, Sakai on Carassius auratus, Youson et al., on Anoplarchus purpurescens, Kobelkowsky (1999) on Bairdiella chrysoura and Stellifer lanceolatus; Kobelkowsky (2005a) on Astyanax fasciatus, and Kobelkowsky (2005b) on Goodea atripinnis. The diversity of the excretory ducts of teleosts is described by Kobelkowsky (2007).

The scarce published dissection techniques of the kidney of teleosts are extremely scarce and not detailed enough (Chiasson; Gerlach et al., 2011; Moreira-Filho \& Bertollo, 1991). 
Exposition and extraction of the kidney of higher teleosts for anatomic, histological and endocrinologic research have a certain technical difficulty, due to its long location from the base of neurocranium to the first caudal vertebra. Its extraction might be incorrect if some structures contacting the kidney or traversing its tissues are not considered.

The objectives of this study are to provide the anatomic description, topographical relationships, and implementation of a dissection technique of the excretory system of L. griseus.

\section{MATERIAL AND METHOD}

Adult specimens of $L$. griseus were collected by means of several fishing techniques, in the coastal lagoons of Pueblo Viejo, Tampamachoco, and Alvarado, Veracruz. The specimens were fixed in $10 \%$ formaldehyde and preserved in $70 \%$ ethanol. An anatomic analysis was made in 10 adult specimens, which standard length ranged from 90 to $176 \mathrm{~mm}$, with an average of $133 \mathrm{~mm}$.
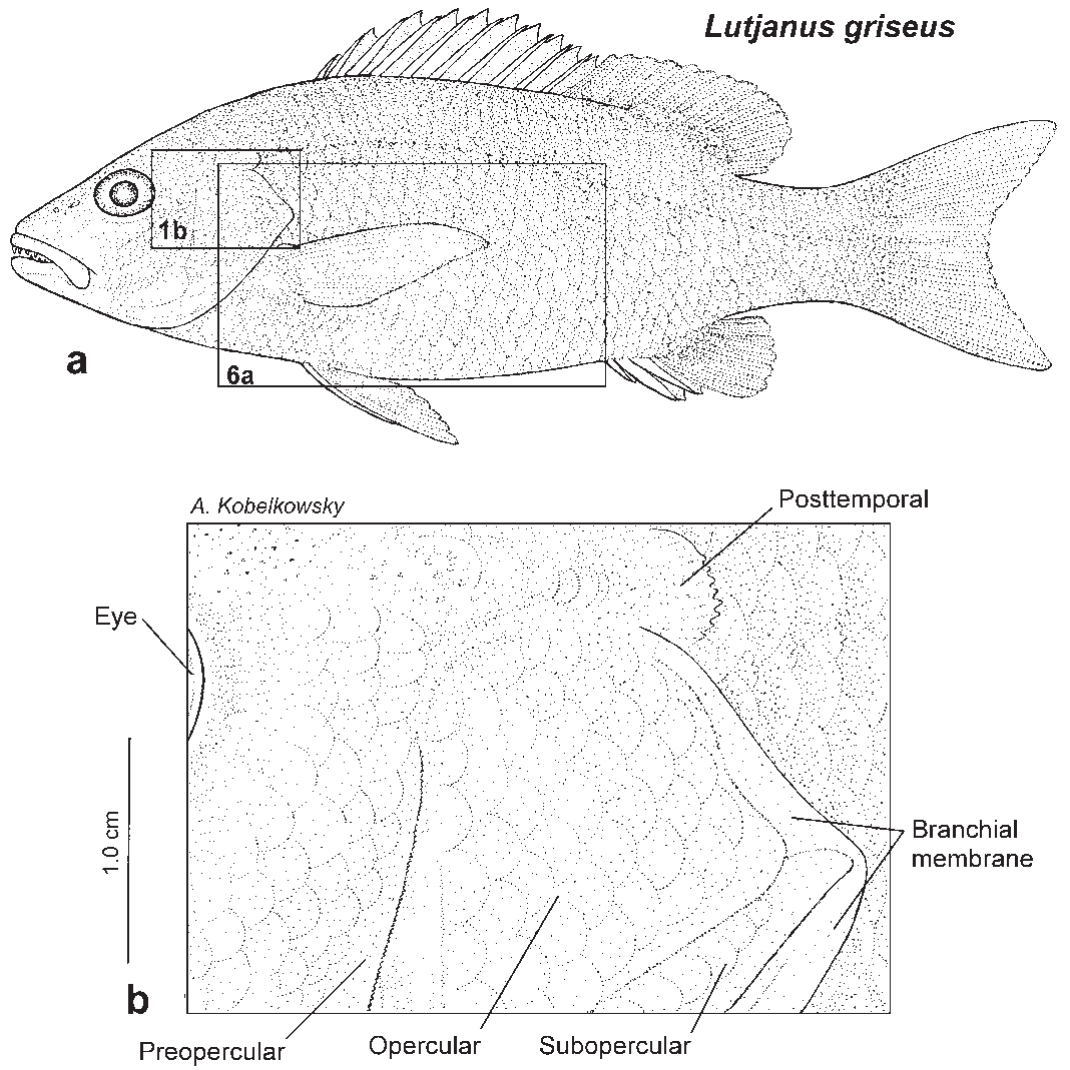

Fig. 1. a) Specimen of Lutjanus griseus in left lateral view, showing the areas corresponding to figures $1 \mathrm{~b}$ and $6 \mathrm{a}$. $\mathrm{b}$ ) Area of the head between the eye, the posttemporal bone, and the edge of the branchial membrane.
According to Figure 1a, the fixed specimen of $L$. griseus is positioned with one side up, and at the beginning of the procedure of exposing the anterior renal lobes, the skin was removed from the temporal region of the head. For the exposure of the rest of the kidney, the skin was removed from the area between the lateral line, the scapular girdle, and the mid-ventral line up until the beginning of the anal fin. The subsequent steps are described in the technique for the dissection of the kidney of this species.

Comparisons were made between the kidneys of $L$. griseus and the following species of teleosts: Elops saurus (Elopidae), Ophichthus gomesi (Ophichtidae), Brevoortia patronus (Clupeidae), Anchoa mitchilli (Engraulidae), Notropis boucardi (Cyprinidae), Astyanax fasciatus (Characidae), Ictalurus balsanus (Ictaluridae), Cathorops melanopus (Ariidae), Rhamdia guatemalensis (Pimelodidae), Oncorhynchus mykiss (Salmonidae), Synodus foetens (Synodontidae), Opsanus beta (Batrachoididae), Zalieutes elater (Ogcocephalidae), Mugil cephalus (Mugilidae), Chirostoma humboldtianum (Atherinopsidae), Strongylura marina (Belonidae), Hyporhamphus roberti (Hemiramphidae), Poecilia butleri (Poeciliidae), Goodea atripinnis (Goodeidae), Syngnathus scovelli (Syngnathidae), Synbranchus marmoratus (Synbranchidae), Scorpaena plumieri (Scorpaenidae), Prionotus maculatus (Triglidae), Centropomus undecimalis (Centropomidae), Micropterus salmoides (Centrarchidae), Eugerres plumieri (Gerreidae), Conodon nobilis (Haemulidae), Bairdiella chrysoura (Sciaenidae), Petenia splendida (Cichlidae), Thalassoma lucasanum (Labridae), Gobionellus oceanicus (Gobiidae), Bothus robinsi (Bothidae), Citharichthys spilopterus (Paralichthyidae), Achirus lineatus (Achiridae), Symphurus plagiusa (Cynoglossidae), Balistes capriscus (Balistidae), and Diodon hystrix (Diodontidae).

The osteological terminology followed Gregory (1959) criterion, and the myological terminology, Winterbottom (1974) criterion. The illustrations were made by means of a camera lucida coupled to a stereoscopic microscope Wild M3Z. 


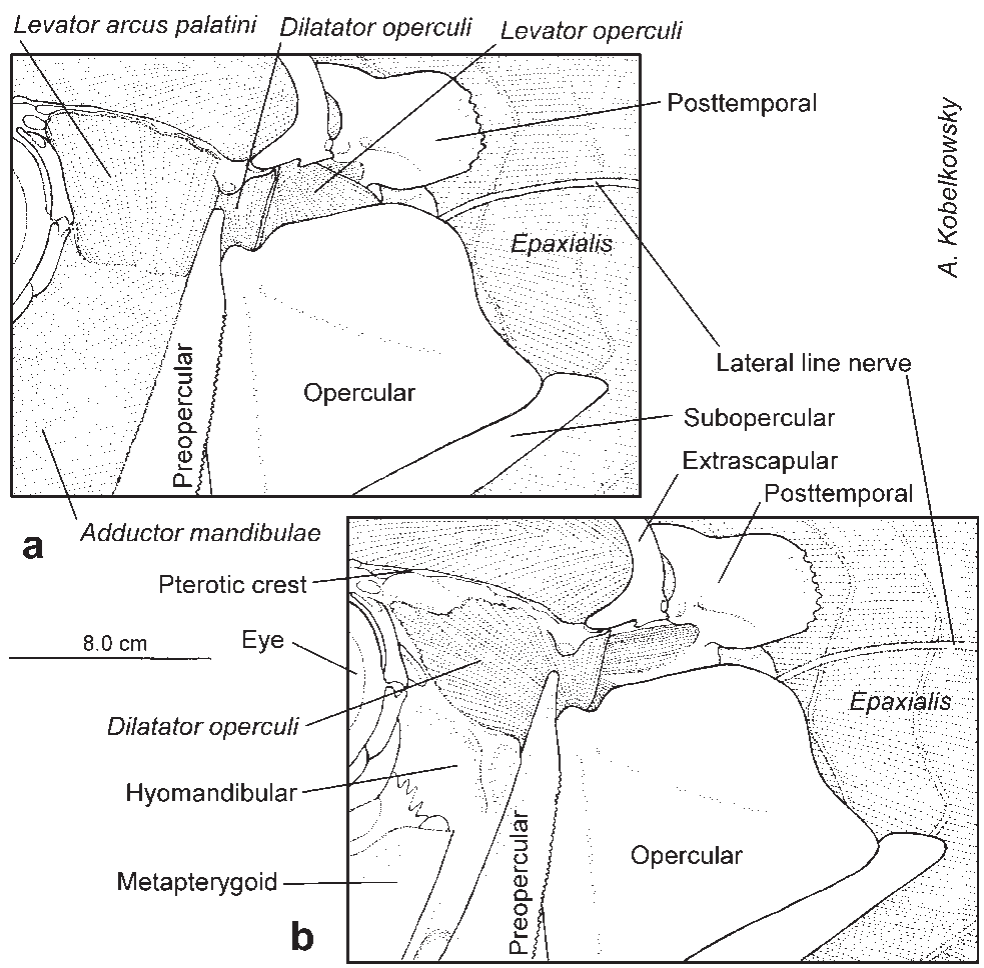

Fig. 2. a) Aspect of the temporal area after removing the skin. b) Aspect of the area after removing the levator arcus palatini, levator operculi, and adductor mandibulae muscles.

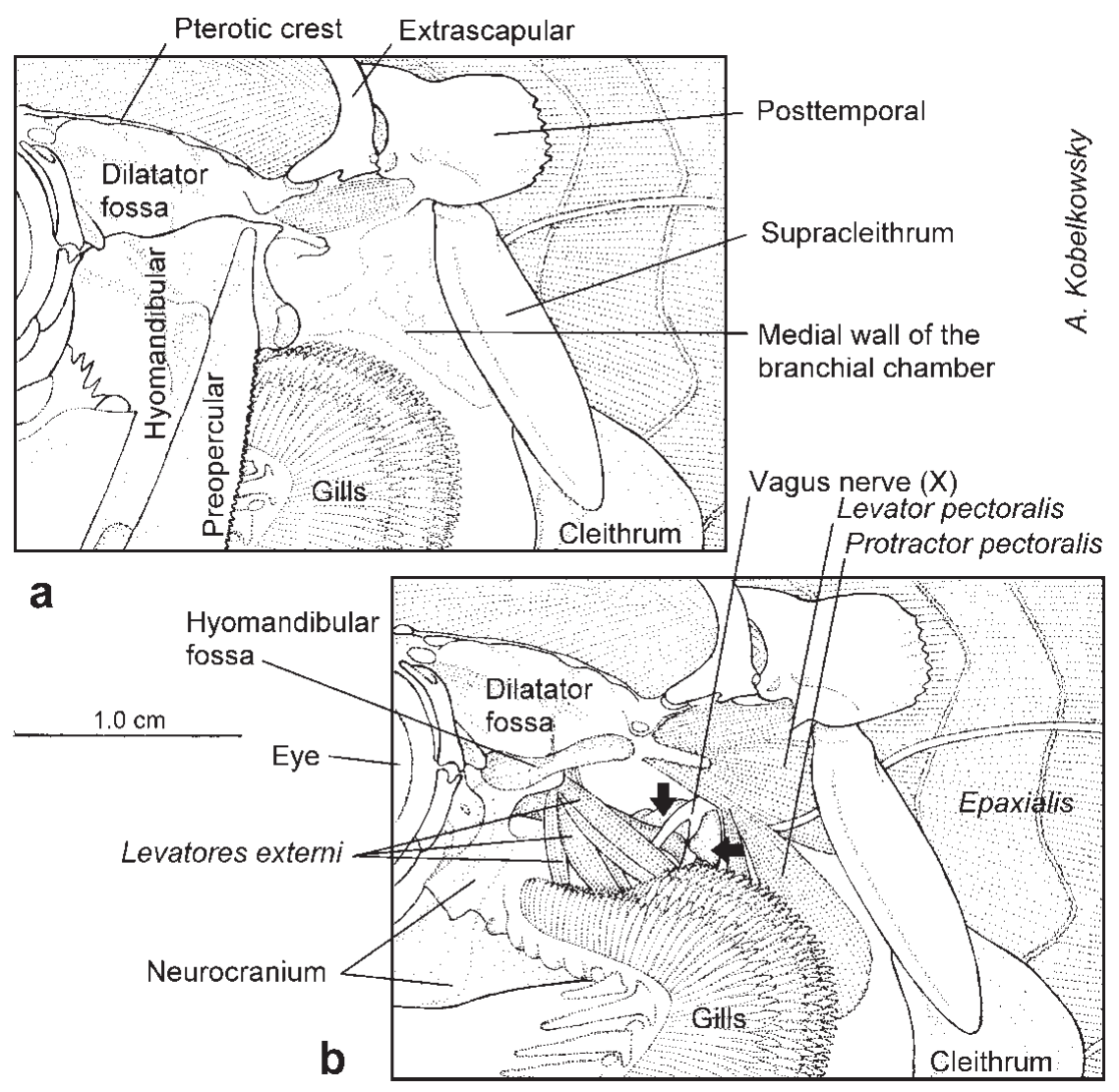

\section{RESULTS}

Morphological description of the kidney. The mesonephric kidney of the grey snapper L. griseus is elongated; it extends from the base of the neurocranium to the first caudal vertebra. Its largest length dorsally makes contact with the centra of the precaudal vertebrae and in its ventral part it makes contact with the gas bladder (Fig. 6a). Laterally, it is limited by the parapophyses of the vertebrae 7 -10. Its posterior border is oblique and makes contact with the first hemal arch and part of the first pterygiophore of the anal fin.

Right and left kidneys fuse throughout approximately half of its length (Fig. 8). The anterior portions are separated from each other by the retractores dorsales muscles of the branchial arches and by the anchorage of the gas bladder to the second vertebral centrum (Fig. 7). The most anterior parts of the separated portions, called "anterior renal lobes", are bulky and irregularly shaped (Figs. 5 to 9).

Each anterior renal lobe is in contact dorsally with the base of the neurocranium (Figs. 4 to 8), and its lateral surface is marked by the passing of the anterior cardinal vein, the vagus nerve $(\mathrm{X})$, the first two spinal nerves (Figs. $4 \mathrm{~b}$ and 5a,b), the dorsal branchial muscles, and the Baudelot's ligament (Figs. 4a, 5a,b and 6b).

Anteroventrally, each renal lobe strongly attaches to the sinus venosus of the heart (Figs. 4b, 5a,b and 6a,b). In the site where the anterior cardinal vein joins the sinus venosus, there is the opening of the posterior cardinal vein (Figs. 7a,b, 8 and 9). The opening of the right posterior cardinal vein is notably bigger than that of the left side (Figs. 7b, 8 and 9).

Fig. 3. a) Aspect of the area after removing the dilatator operculi muscle and the opercular bone. b) Aspect of the area after disarticulating and removing the hyomandibular, metapterygoid, and preopercular bones. (Arrows point to small portion of the left anterior renal lobe) 


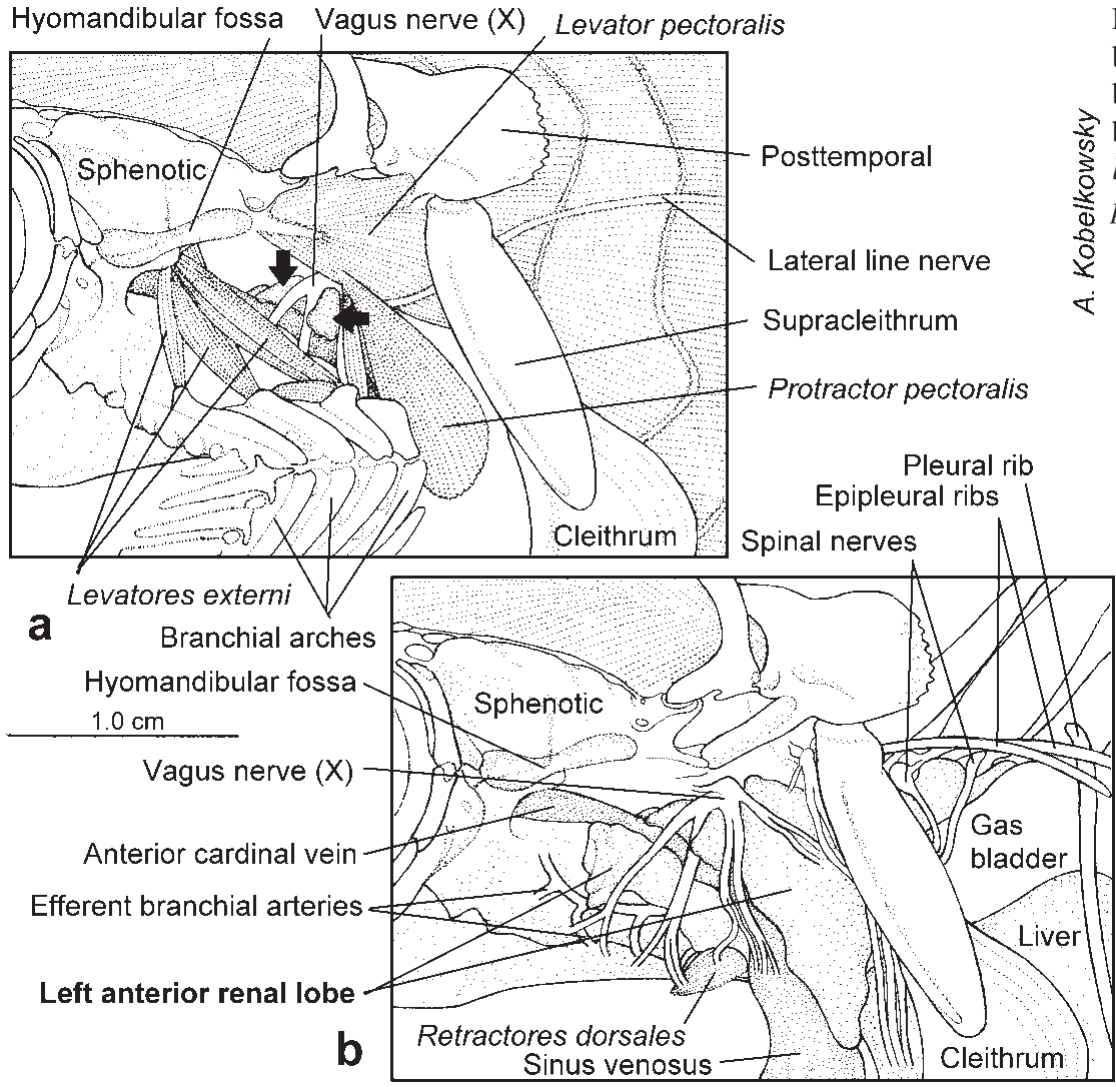

Fig. 4. a) Aspect of the area after detaching the branchial lamellae from the branchial arches. b) Aspect of the area after removing the branchial arches and the levatores externi, levatores interni, levator posterior, levator pectoralis, and protractor pectoralis muscles. the first two hemal bridges go through the renal mass, while the last one leaves a mark in the shape of a transversal groove (Fig. 9a).

The caudal vein enters the kidney through the postero-dorsal angle, at the level of the first hemal arch (Figs. 6a and 9a). Inside the kidney, this vein is divided into the two posterior cardinal veins, of which the right one has a bigger development (Fig. 8). The right posterior cardinal vein goes through the right anterior renal lobe (Figs. 7 and 8), and enters the right part of the sinus venosus of the hearth. The dorsal aorta, which results from the union of the efferent branchial arteries,

In its posterior portion, each anterior renal lobe is perforated by the Baudelot's ligament (Figs. 5b, 6a, b and $9 a)$, which originates from the basioccipital bone and is inserted on the inner surface of the supracleithrum, surrounding the upper border of the cleithrum (Fig. 5a).

The borders of the rest of the kidney show tips corresponding to the position of the vertebral centra (Figs. 7 and 8). The presumptive corpuscle of Stannius is located on one side of the most posterior part of the kidney (Figs. 6a and 9a).

Fig. 5. a) Aspect of the area after removing the supracleithrum bone. b) Aspect of the left Branchial efferent arteries anterior renal lobe after removing the cranial and spinal nerves, as well as the upper portion of the cleithrum.

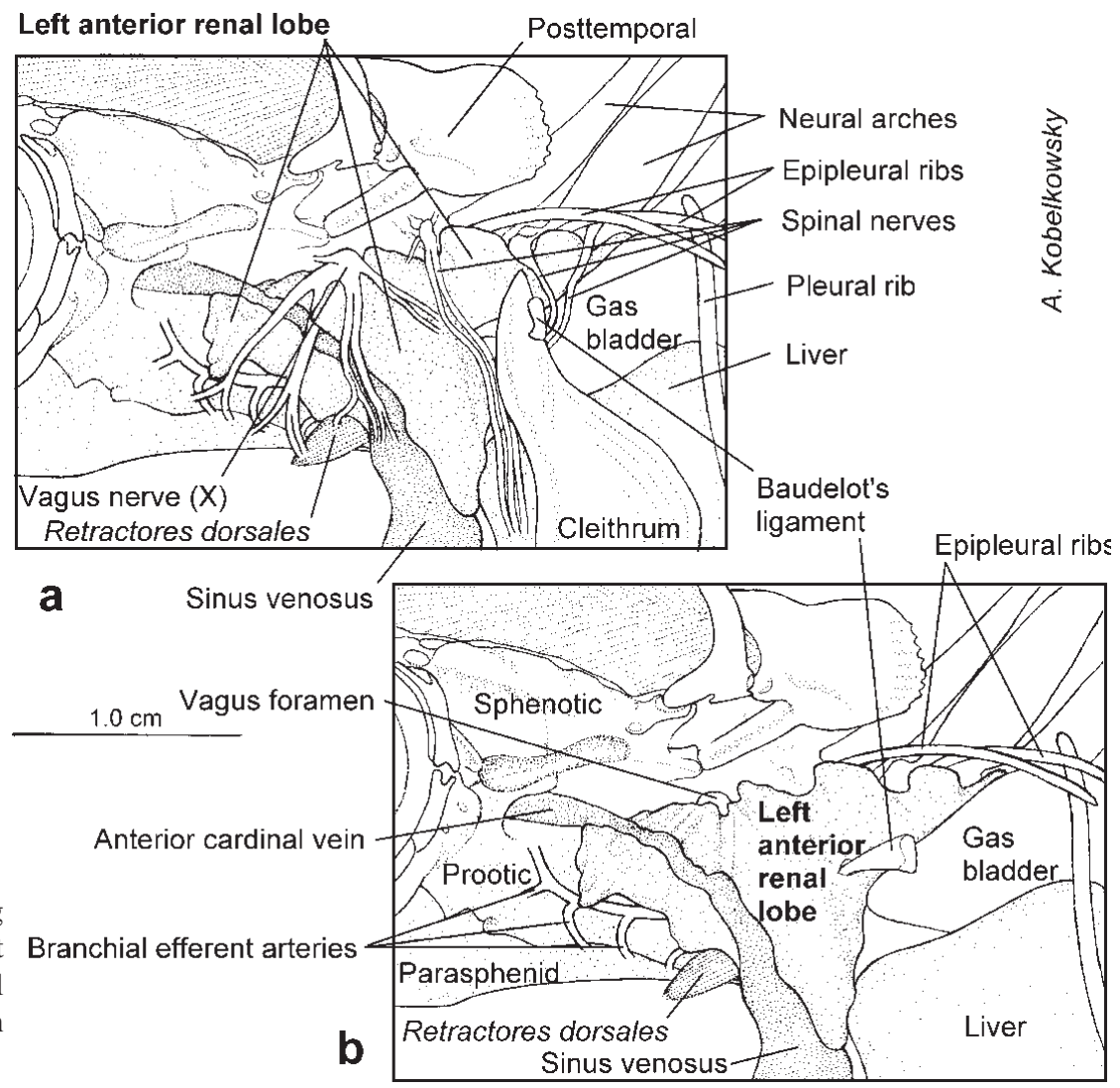



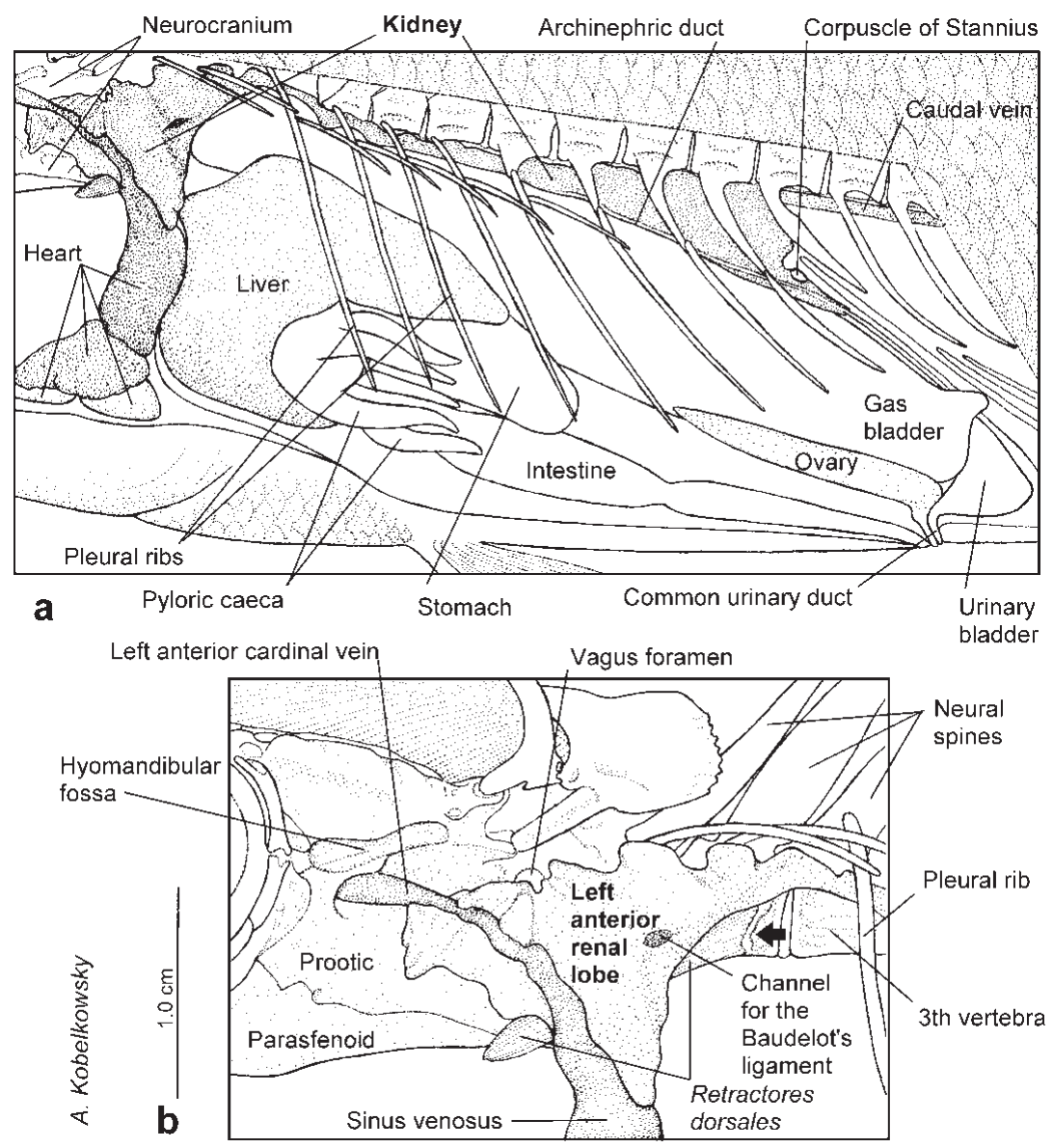

Fig. 6. a) Left aspect of the visceral cavity after removing the skin and the myotomes of the area between the scapular girdle, the lateral line, the origin of the anal fin, the ventral midline, and the pelvic girdle. b) Aspect of the left anterior renal lobe after removing the Baudelot's ligament, the efferent branchial arteries, as well as the anterior part of the gas bladder and of the liver. (The arrow points the left main site of attachment of the gas bladder).

In females, the urinary bladder continues as the common urinary duct (Fig. 7a), and it opens out in the urinary papilla (Fig. 9b). In males, it continues as the urogenital duct, and it opens out in the urogenital papilla (Fig. 9c). In both sexes the corresponding papillae are located behind the anus.

\section{Comparison with other teleost species.}

The kidney of L. griseus is morphologically similar to that of $M$. cephalus, O. beta, and the Perciformes species, $C$. undecimalis, $M$. salmoides, $E$. plumieri, C. nobilis, B. chrysoura, $P$. splendida, T. lucasanum, and $G$. oceanicus, in which the anterior renal is located between the kidney and the vertebral centra (Fig. 7).

The archinephric ducts are located on the lateroventral borders of the kidney (Figs. 6a, 8 and 9a), and after leaving this organ both ducts attach to each other. The two archinephric ducts make contact with the upper part of the urinary bladder (Fig. 9a). This last one is symmetric, laterally triangular, and is located at the posterior end of the gas bladder, which marks two concavities in its anterior surface.

Fig. 7. a) Ventral view of the heart, anterior renal lobes and retractores dorsales muscles after removing the digestive tract and the gas bladder. b) Ventral view of the anterior renal lobes and the retractores dorsales after removing the heart. Notice the two openings of the posterior cardinal veins.

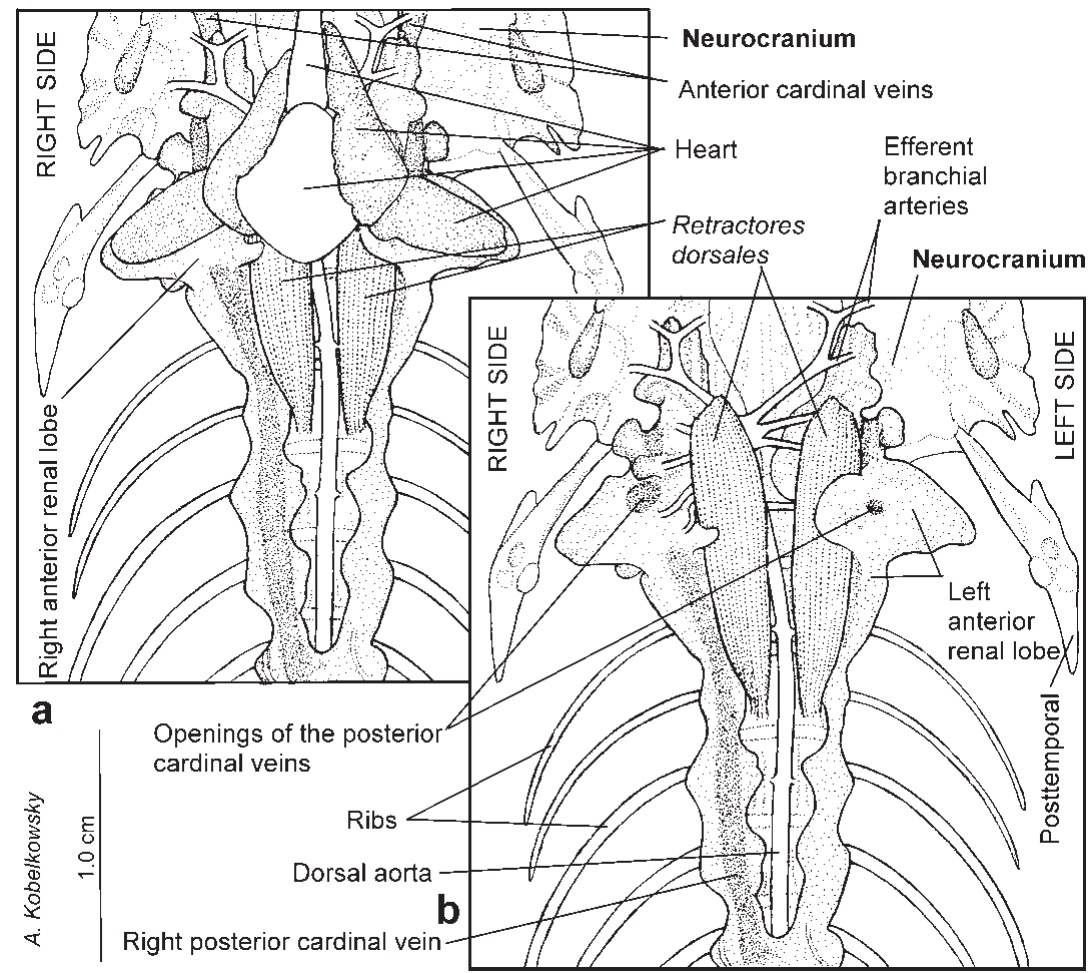




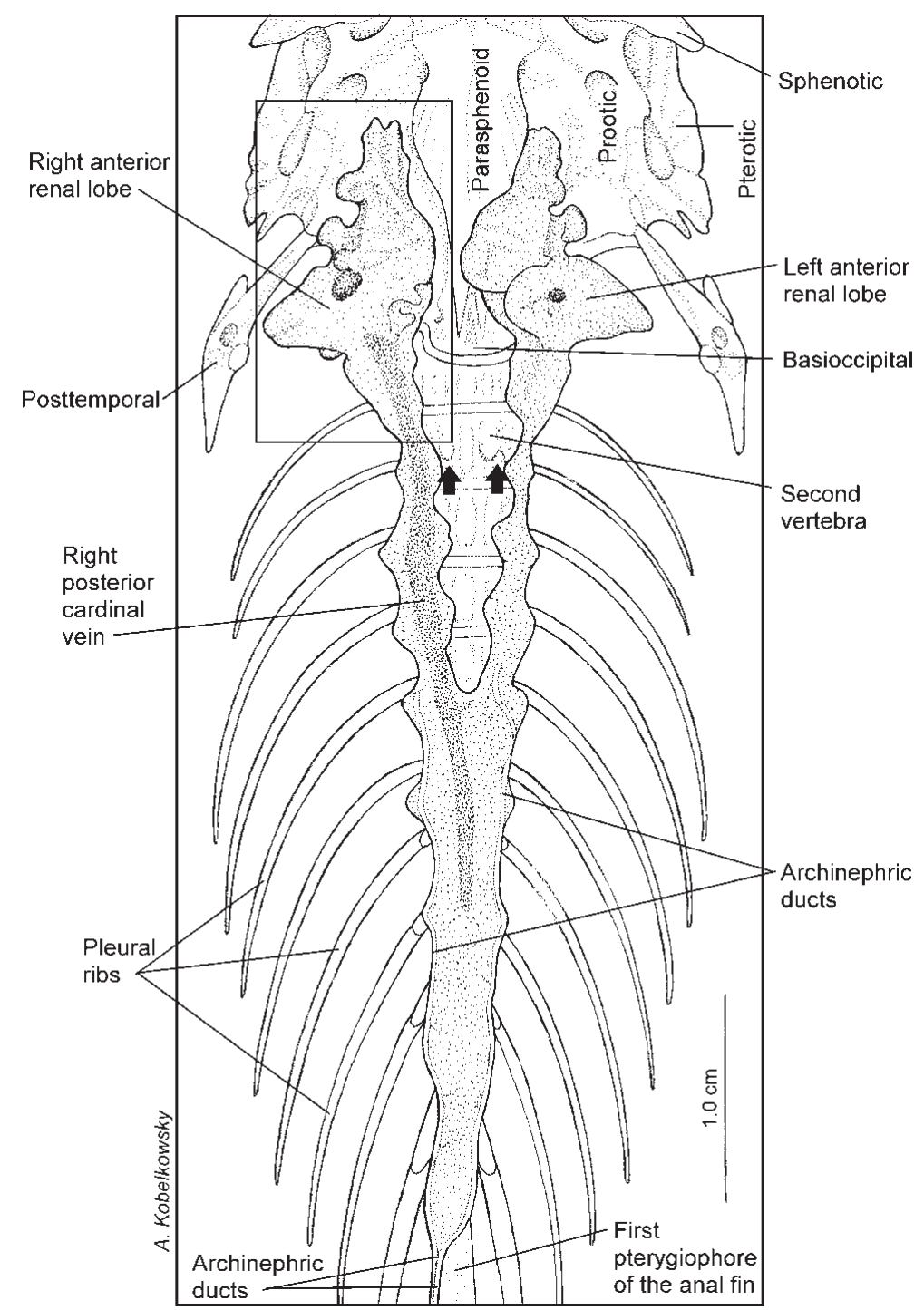

Fig. 8. Ventral view of the complete kidney after removing the retractor dorsalis muscles, the dorsal aorta, and the efferent branchial arteries. The right anterior renal lobe is delimited by the inner box. (The arrows indicate the main anchorage sites of the gas bladder).

lobes are separated from each other by the retractores dorsales muscles and the gas bladder.

Similarly, the anterior renal lobes of the Pleuronectiformes species (B. robinsi, C. spilopterus, A. lineatus, and S. plagiusa) are separated from each other only by the retractores dorsales; however, there is no gas bladder.

In contrast, both right and left kidneys are completely separated each other by means of the retractores dorsales in species such as: $Z$. elater, and D. hystrix.

Dissection technique of the kidney. Remove the skin from the tempo- ral region of the head (Fig. 1a,b), between the ocular orbit, posttemporal bone, and the branchial membrane in order to expose the following muscles: levator arcus palatini, dilatator operculi, levator operculi, part of the adductor mandibulae and part of the epaxialis musculature (Fig. 2a).

Remove the muscles above mentioned with the exception of the epaxialis musculature, to expose the dilatator operculi muscle and the upper part of the hyomandibular bone (Fig. 2b).

Disarticulate and remove the opercular and subopercular bones to expose the medial wall of the branchial chamber, the supracleithrum and the upper part of the gills (Fig. 3a).

Detach the tissues forming the medial wall of the common branchial chamber (Fig. 3b); disarticulate the hyomandibular, remove the upper part of this bone and of the preopercular to expose the dorsal muscles of the branchial arches, as well as the levator pectoralis and the protractor pectoralis muscles. Observe, between the levatores externi and the levator posterior, part of the left anterior renal lobe (indicated by arrows).

Detach the branchial lamellae from the upper branches of the branchial arches to expose the epibranchial bones and the levatores externi, levator posterior, protractor pectoralis, and levator pectoralis muscles (Fig. 4a).

Remove the muscles above mentioned and the anterior portion of the epaxialis musculature, in order to reveal most of the left anterior renal lobe, the vagus nerve, the first two spinal nerves, and the left anterior cardinal vein (Fig. 4b). Likewise, part of the gas bladder and of the liver is exposed.

Remove the supracleithrum by disarticulating it from the posttemporal and separating the distal end of the Baudelot's ligament, in order to uncover a greater extension of the left anterior renal lobe, the first two spinal nerves, together with the upper portion of the cleithrum (Fig. 5a).

Remove the upper portion of the cleithrum, and the cranial and spinal nerves of 


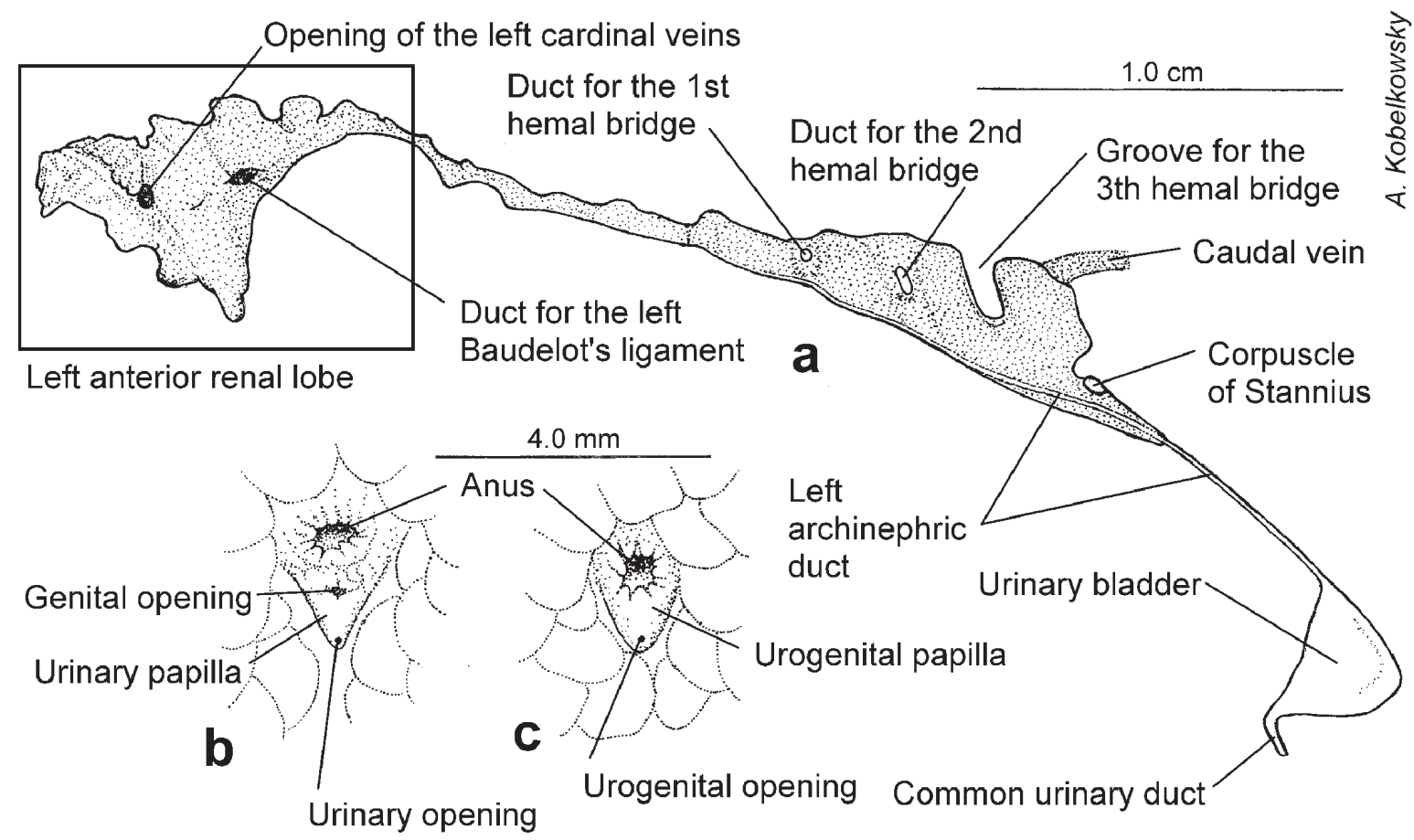

Fig. 9. a) Left lateral view of the complete excretory system. b) Ventral view of the anus and urinary papilla in females. c) Ventral view of the anus and urogenital papilla in males.

the area, so as to observe the surface of the left anterior renal lobe, the left anterior cardinal vein, the left Baudelot's ligament, and the left efferent branchial arteries (Fig. 5b). Observe the most anterior part of the gas bladder and liver.

Remove the skin from the left side of the body, between the scapular girdle, the lateral line, the origin of the anal fin, the ventral midline, and the pelvic girdle (Fig. 1a), in order to expose the axial musculature of the area. Next, take away this musculature until the epipleural and pleural ribs and the organography of the visceral cavity are exposed (Fig. 6a). Likewise, remove the left pectoral musculature and the rest of the bones of the left scapular girdle in order to show the heart.

Remove the gas bladder. Observe the upper part of the sinus venosus of the heart, the left anterior cardinal vein, part of the left retractor dorsalis muscle, and most of the left anterior renal lobe (Fig. 6b).

Remove the digestive tract, by cutting transversely the oesophagus and the rectus, and separate the liver by sectioning the hepatic veins. In the same way, take away the gonads and the spleen.

Observe ventrally the heart, the left and right anterior renal lobes, the left and right anterior cardinal veins, the right posterior cardinal vein, part of the left and right retractor dorsalis muscles, the dorsal aorta, and the first precaudal vertebrae (Fig. 7a).

Separate the heart and the left and right anterior cardinal veins, by sectioning their contact with the posterior cardinal veins, to expose the retractor dorsalis muscles, the efferent branchial arteries, and the dorsal aorta (Fig. 7b).

Remove the retractor dorsalis muscles, the dorsal aorta, and the efferent branchial arteries to have a ventral view of the complete kidney (Fig. 8). Observe its contact with the posterior region of the neurocranium and with the precaudal vertebrae. Notice the main anchorage sites of the gas bladder to the second vertebrae (arrows).

Remove the pleural and epipleural ribs from the left side, cut the left parapophyses (transverse processes), and the hemal bridges, which are located in the last three precaudal vertebrae. Remove as well, the first hemal arch.

Observe laterally the complete kidney, the left archinephric duct, the urinary bladder (Fig. 9a). Similarly, recognize the common urinary duct in females, and the urogenital duct in males.

Observe ventrally the anus and the urinary papilla with the genital and urinary openings in females (Fig. 9b), and the urogenital papilla with the urogenital opening in males (Fig. 9c). 


\section{DISCUSSION}

The morphological analysis of the kidney of 37 species, from 30 families of Mexican teleostean fishes, showed a great diversity of shapes. Likewise, Ogawa recognize the diversity of marine teleostean fishes, grouping them in five categories.

The shape and the relief of the kidney are determined by the contact with a considerable number of neighboring structures. Thus, the dorsal surface of a great part of the kidney has an impression of the precaudal vertebrae centra and of the dorsal aorta; the parapophyses of the vertebrae are laterally marked; the hemal bridges mark grooves and a channel; and the characteristic curve of its ventral surface coincides with the curvature of the dorsal surface of the gas bladder. The anterior portion of the kidney, or anterior renal lobes, is the most complex in shape, since it is affected by the pass of the retractores dorsales muscles, the attachment of the gas bladder, the anterior cardinal veins, some cranial and spinal nerves, the dorsal muscles of the branchial arches, the first epipleural ribs, and the Baudelot's ligaments.

The concept in which the neighboring structures determine partially the shape of the kidney is also applied to species of Bairdiella and Stellifer (Sciaenidae), in which the lobes of the anterior chamber of the gas bladder mark a concave surface in the anterior renal lobes (Kobelkowsky, 1999).

As a result of this survey, the recognition of the kidney of L. griseus as a morphological pattern of the higher teleosts (Acanthopterygii) is proposed. This morphological pattern consists of the fusion of the right kidney with the left one in most of its length, with the exception of the anterior portion, which ends as two "anterior renal lobes" that make contact with the neurocranium.

In contrast, there are a few teleost groups with both kidneys completely separated from each other, in a left and a right kidney, as observed in the guppy $P$. butleri, the batfish $Z$. elater, and in the porcupine fish D. hystrix. Mok described this morphological situation in some botoid fishes, dipnoans, polypterids and some euteleosts.

Since in some teleostean fishes there are other renal lobes, like the single anterior renal lobe of $A$. fasciatus, the single posterior renal lobe of B. patronus and of G. oceanicus, the asymmetric caudal renal lobe of $A$. lineatus, and the lateral renal lobes of $N$. boucardi, the name of "anterior renal lobes" of the higher teleosts is proposed.

The structures that, in upper teleosts, usually separate the anterior or cephalic part of the kidney into two anterior renal lobes are the retractor dorsalis muscles, and the attachment to the first vertebrae of the gas bladder. Such muscles are considered in the diagnosis of the Acanthopterygii by Rosen (1973). Unlike the remaining classes of vertebrates, the anterior renal lobes of L. griseus and of other studied teleosts make contact with the neurocranium, and with the heart. The addition to the diagnosis of Acanthopterygii of the following characters is proposed: the presence of the two anterior renal lobes, which are in contact with the neurocranium and the attachment of the gas bladder to the first vertebrae.

Although the adult Pleuronectiformes does not have gas bladder, the retractor dorsalis separate both short anterior renal lobes.

In the terminology of the kidney components of the teleostean fishes, authors such as Hickman \& Trump (1969) called the anterior portion of the organ "head kidney", and the remaining portion "trunk kidney". Reimschuessel divided the kidney into "cranial or head kidney" and "caudal kidney". The so-called cephalic, cranial or head kidney is assigned hematopoietic and endocrine functions, while the trunk or caudal kidney portion, an excretory function. However, in the present study, this terminology is rejected, since morphologically the kidney of the gray snapper L. griseus, just like of many other teleosts, is not physically separated in an anterior and a posterior organ.

The general shape of the kidney of L. griseus corresponds to the type III of the classification of marine teleosts of Ogawa, who describes it as an organ with the posterior portion fused and the anterior one represented by two slender branches.

The outstanding asymmetry of the posterior cardinal veins, with the most development of the right one, in L. griseus corresponds to that observed in the rest of the examined species, and it is coincident with the description of Iwamizu \& Itazawa (1989) of the kidney of Seriola quinqueradiata (Carangidae), Ogawa of many teleosts, and Mok of Amia cal$v a$ and some teleosts, and may be the morphological pattern for the higher teleosts.

The anatomic characters above described can be observed following the present dissection protocol, which, in addition, allows to take into account those neighboring structures that make the total exposition of the kidney difficult, including those that cross the renal tissue and may cause the rupture of the organ when the researcher tries to remove it.

KOBELKOWSKY, A. Morfología y técnica de disección del riñón del pargo gris Lutjanus griseus (Teleostei: Lutjanidae). Int. J. Morphol., 31(2):553-561, 2013. 
RESUMEN: Con el objeto de describir la morfología del riñón y de implementar su técnica de disección, se analizaron ejemplares del pargo gris Lutjanus griseus. La morfología del riñón corresponde al patrón estructural de los teleósteos superiores, consistiendo en una amplia fusión del riñón derecho con el izquierdo, con excepción de los lóbulos renales anteriores. Ambos lóbulos renales anteriores están separados por los músculos retractores dorsales y por el anclaje de la vejiga gaseosa a las vértebras. Algunas estructuras marcan la superficie del riñón, como algunos de los nervios craneales y espinales, las costillas, vasos sanguíneos, el ligamento de Baudelot, el seno venoso del corazón, las vértebras precaudales y la vejiga gaseosa. Los conductos arquinéfricos se conectan a la vesícula urinaria, desde la cual sale el conducto urinario común.

PALABRAS CLAVE: Mesonefros; Peces; Anatomía; Morfología renal; Técnica de disección.

\section{REFERENCES}

Castro-Aguirre, J. L. Catálogo sistemático de los peces marinos que penetran a las aguas continentales de México, con aspectos zoogeográficos y ecológicos. México, Instituto Nacional de Pesca, 1978.

Chiasson, R. B. Laboratory anatomy of the perch. Dubuque, W.M.C. Brown, 1980.

Gerlach, G. F.; Schrader, L. N. \& Wingert, R. A. Dissection of the adult zebrafish kidney. J. Vis. Exp., (54)pii:2839, 2011.

Gérard, P. Organes uro-genitaux. In: Grassé, P. P. (Ed.). Traité de Zoologie. Anatomie, Systematique, Biologie. Tome XII. Paris, Masson et Cie., 1954. pp.1565-83.

Grassi Milano, E.; Basari, F. \& Chimenti, C. Adrenocortical and adrenomedullary homologs in eight species of adult and developing teleosts: morphology, histology, and immunohistochemistry. Gen. Comp. Endocrinol., 108(3):483-96, 1997.

Gregory, W. K. Fish skulls. A study of evolution of natural mechanisms. Florida, Eric Lundberg, 1959.

Hickman, C. P. \& Trump, B. F. The kidney. In: Hoar, W. S. \& Randall, D. J. (Eds.). Fish Physiology. London, Academic Press, 1969. pp.91-239.

Iwamizu, M. \& Itazawa, Y. Gross anatomy of the vascular system and the lateral musculature of the yellowtail Seriola quinqueradiata (Carangidae). Japan. J. Ichthyol., 36(2):232-51, 1989.

Kobelkowsky, D. A. El sistema urogenital de los géneros Bairdiella y Stellifer (Pisces: Sciaenidae). Rev. Mex. Hist. Nat., 49:153-62, 1999.

Kobelkowsky, D. A. Sistema urogenital de los lenguados de la familia Achiridae (Pisces: Pleuronectiformes) del Golfo de México. Hidrobiológica, 10(1):51-60, 2000.

Kobelkowsky, A. El sistema excretor de Astyanax fasciatus (Teleostei: Characidae). Vertebrata Mexicana, 17:1-6, 2005a.

Kobelkowsky, A. General anatomy and sexual dimorphism of Goodea atripinnis (Teleostei: Goodeidae). In: Uribe M. C. \& Grier, H. (Eds.) Viviparous Fishes. Homestead, New Life, 2005b. pp.483-98.
Kobelkowsky, A. Diversidad morfológica del sistema de conductos excretores de los peces teleósteos. Rev. Mex. Biodiv., 78(1):105-16, 2007.

Lagler, K. F.; Bardach, J. E.; Miller, R. R. \& May Passino D. R. Ictiología. México D. F., AGT Editor, 1977.

Mok, H. K. The posterior cardinal veins and kidneys of fishes, with notes on their phylogenetic significance. Japan. J. Ichthyol., 27(4):281-90, 1981.

Moreira-Filho, O. \& Bertollo, L. A. C. Extraction and use of the cephalic kidney for chromosome studies in small fish. Brazil J. Genet., 14(4):1085-90, 1991.

Nelson, J. S. Fishes of the World. New York, John Wiley \& Sons, 2006.

Ogawa, M. Comparative study of the external shape of the teleostean kidney with relation to phylogeny. Sci. Rep. Tokyo Kyoiku Daigaku, B10:61$8,1961$.

Reimschuessel, R. A fish model of renal regeneration and development. ILAR J., 42(2):285-91, 2001.

Rosen, D. E. Interrelationships of higher euteleostean fishes. In: Greenwood, P. H.; Miles, R. S. \& Patterson C. (Eds.). Interrelationships of fishes. London, Academic Press, 1973. pp.397-513.

Sakai, T. The structure of the kidney from the freshwater teleost Carassius auratus. Anat. Embryol. (Berl), 171(1):31-9, 1985.

Winterbottom, R. A. A descriptive synonymy of the striated muscles of the Teleostei. Proc. Acad. Nat. Scienc. Phil., 125:225-317, 1974.

Youson, J. H.; Butler, D. G. \& Tsioros, K. The kidney, adrenocortical homolog, and corpuscles of Stannius in the Cockscomb Prickleback Anoplarchus purpurescens. Japan. J. Ichthyol., 36(1):53-62, 1989.

Dirección para Correspondencia:

Abraham Kobelkowsky

Laboratorio de Peces. Departamento de Biología

Universidad Autónoma Metropolitana

Unidad Iztapalapa

Av. San Rafael Atlixco 186. Col. Vicentina

Iztapalapa

09340

México, D.F.

MEXICO

\section{Email: akd@xanum.uam.mx.}

Received: 12-04-2012

Accepted: 01-03-2013 